\title{
A valuation approach of port funding strategies with application to a container terminal concession in Sub-Saharan Africa
}

\author{
Darren Fraser \\ Department of Maritime Studies, Durban University of Technology, \\ Durban, South Africa \\ Thando Mpikeleli \\ South African Institute of Chartered Accountants (SAICA), \\ Johannesburg, South Africa, and \\ Theo Notteboom \\ Faculty of Law and Criminology, Maritime Institute, Ghent University, Ghent, \\ Belgium; Faculty of Business and Economics, University of Antwerp, Antwerp, \\ Belgium and Antwerp Maritime Academy, Antwerp, Belgium
}

\begin{abstract}
Purpose - Increased economic activity in sub-Saharan Africa (SSA) has given rise to increased demand for port development. Given the often scarce availability of national public funding, port institutional reform programmes have been implemented to pave the way for the inclusion of external port investors. Notwithstanding this fact, some sub-Saharan African Governments remain institutionally locked into the notion that state-owned enterprises remain an appropriate vehicle for port terminal operations. This, despite the fact that terminal operational concessions globally and within the continent of Africa are increasingly being managed by global terminal operators. Given this context, this study aims to evaluate different port valuation and funding strategies. Two research questions form the core of this research: what is the financial value of a concession? What is the most cost advantageous funding strategy? The methodology is applied to the development of a two-berth container terminal in SSA.

Design/methodology/approach - After reviewing a range of financial valuation and funding techniques, the study presents valuation and funding model applicability-fit tests. Thereafter, a suitable valuation technique is selected and applied to the case study providing a concession valuation. Different funding strategies are applied to the valuation model to determine the cost implications of each funding instrument given the local context and institutional constraints applicable to SSA. Finally, the study discusses the significance of the results to potential SSA port investors by highlighting the impact of each funding approach on key financial metrics.

Findings - The study presents a range of financial investment appraisal results for the case study concession in consideration of four specific funding strategies. The highest concession valuation could be attributed to a higher debt ratio as a principal funding strategy. In addition, this funding approach $(100 \%$ debt) realised the shortest payback period and the highest internal rate of return values. The authors, however, maintain that the optimal funding strategy for a concession depends ultimately on the financial goals of the investor.
\end{abstract}

(C) Pacific Star Group Education Foundation. Licensed re-use rights only.
Port funding strategies

Received 17 December 2019 Revised 12 June 2020 7 September 2020 Accepted 20 October 2020

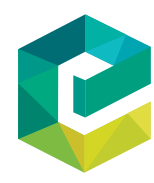

Maritime Business Review Vol. 6 No. 2, 2021 pp. $147-172$ Emerald Publishing Limited 2397-3757 
MABR

6,2

Originality/value - This research makes a contribution to the existing literature on port finance and development by presenting a structured approach to the evaluation of the valuation and funding techniques, which can be used in terminal development subject to the specific local context and institutional constraints (in this case applicable to SSA). The study provides practical insight into the potential cost of the considered terminal concession for private or public sector participants and a view of the most cost advantageous funding strategy available for interested investors.

Keywords Port finance, Public/private partnership, Terminal concession, Terminal funding, Terminal valuation

Paper type Research paper

\section{Introduction}

Seaports are crucial to the growth of regional economies and international trade. Governments and market players are involved in a wide range of port expansion and reconversion projects that should secure additional port infrastructure capacity to cope with anticipated growth in port demand. Port infrastructure investments typically bear specific characteristics (Musso et al., 2006). The planning, design and development time of port infrastructure projects take a lot of time (typically 5 to 15 years for large port projects). Combined with the long economic life of these structures (50 years or more), this leads to a time lag between costs and revenues, a long payback period and high risks and uncertainty associated with revenues and costs (e.g. cost overruns are common). Furthermore, port infrastructures often represent sunk costs, i.e. lost whenever the investor decides to withdraw from the market. Port infrastructure profitability is partly indirect as port infrastructures act as economic engines for the development of other activities (positive externalities). However, they also generate negative externalities such as environmental costs.

Generally, ports have control over their infrastructure but must compete for funding to improve them. In many parts of the world, a long-standing debate exists over how to fund new seaport infrastructure and development (Cook, 2010 on the situation for US ports). Typical funding options include public-private partnerships (PPPs), public bank loans (e.g. The World Bank), community and regional development funds, private bank loans, equity and initial public offerings (IPOs, Satta et al., 2017). Port infrastructure finance is also a key issue in Africa (Farrell, 2014). There has been a considerable increase in African port developments following the sustained growth in gross domestic product levels on the continent in the past decade. Institutional reforms at the port level were/are often required to widen the funding options available to African ports. While some studies have demonstrated the impact of institutional reform programmes on port efficiencies (e.g. the application of efficiency measures such as production frontier models (Trujillo et al., 2013) and the quantitative application of Malmquist productivity indexes (Cheon et al., 2010)), there is scope to explore the practical implication of port concessioning as it pertains to the financial valuation and funding aspects relating to port terminal concessions. This is particularly interesting in an African context in which some governments remain institutionally locked into the notion that state-owned enterprises remain an appropriate vehicle for port terminal operations.

This study analyses and evaluates the implications of different funding strategies associated with the development of a two-berth port terminal in sub-Saharan Africa (SSA) within the specific institutional context whereby government state-owned entities own and operate port infrastructure and superstructure. Two research questions form the core of this research: 
$R Q 1$. What is the financial value of the concession?

$R Q 2$. What is the most cost advantageous funding strategy applicable to this concession given the institutional constraints?

To answer these research questions, the value of a case-specific concession is financially modelled to determine an appropriate business valuation for the concession using various financial valuation modelling techniques. This is undertaken by reviewing popular financial valuation techniques and thereafter, assessing the practical applicability of each to this case study. To realise the study objectives, we firstly provide a contextual setting of the subSaharan region, as well as the theoretical framework associated with business valuations and funding models. In doing so the authors consequently develop the conceptual framework for this study. Secondly, in our methodology, we perform a valuation and funding model applicability-fit test by assessing the relevance of the identified models to our case. Thereafter, a suitable valuation technique is selected and applied to our case ultimately providing a concession valuation. Thirdly, different funding strategies are applied to the valuation model to determine the cost implications of each funding instrument available to fund the concession given the local context and institutional constraints applicable to subSaharan Africa. Finally, the study discusses the significance of the results to potential SSA port investors by highlighting the impact of each funding approach on the key financial metrics computed by the authors.

\section{Contextual setting: the sub-Saharan port system and its infrastructure deficit}

Geographically, SSA is the area on the continent of Africa south of the Sahara desert. According to IMF's October 2019 global activity economic growth projections, the SSA region's economic growth in pre-COVID-19 times was projected to increase from $3.6 \%$ in 2020 to $4.2 \%$ in 2024. For South Africa, however, (one of the region's largest economies) the growth outlook remains subdued with growth projections below $2 \%$. This is compared to two-fifths of the region's expected average growth rate which is projected to exceed $5 \%$ over the medium term. The World Bank (2020) estimated that the COVID-19 pandemic will cost the SSA region between USD 37 and USD 79bn in output losses in 2020. The newest figures point to an economic contraction from $2.4 \%$ in 2019 to between -2.1 and $-5.1 \%$ in 2020 . The COVID-19 pandemic is also affecting the largest economies in the region, i.e. Nigeria, South Africa and Angola with South Africa having the largest number of confirmed cases in the region.

The lack of port and transportation infrastructure in many SSA countries remains one of the primary limiting factors towards the achievement of the region's true growth potential. Underdeveloped, poorly maintained and inadequate port, road and rail infrastructure networks inhibit trade, the flow of goods and the mobility of people. This constrains the true growth potential of the resource-rich region. While the presence of freight transport infrastructure alone does not guarantee economic transformation (other dependencies such as operational efficiencies and effective management are also required), it certainly does provide the basis on which sustainable growth and economic development can thrive. Ceteris paribus, increasing port capacity enhances service quality and should, therefore, attract and accommodate more traffic to the port (Xiao et al., 2012; Fraser and Notteboom, 2015a). Port capacity investments, however, are very costly given their capital-intensive nature (Haralambides, 2002) and as such unaffordable to many financially constrained governments in SSA.
Port funding
strategies 
MABR

6,2
A rather recent trend in SSA is the stronger involvement of Chinese state-owned companies in port investments. Chinese companies such as China Merchants Holdings International (CMHI), China Harbour and China State Construction (CSC) have proven to be very instrumental in the realisation of the key port expansion and rehabilitation projects across SSA using different investment and funding modes such as PPP arrangements (e.g. build operate transfer or BOT), $\mathrm{EPC}+\mathrm{F}+\mathrm{I}$ (engineering procurement construction + finance + invest) and acquisitions. Many of the more recent port projects, particularly on Africa's East coast, have been realised in the framework of the New Maritime Silk road as part of the belt and road initiative (BRI) introduced in 2013 by China's President Xi Jinping (Lee et al., 2018). However, also South and West Africa have welcomed Chinese investors. An example is the new Walvis Bay container terminal project in Namibia, which was built by China Harbour and handed over to the Namibian Port Authority in 2019 which remains both the port authority and port operator. The greenfield Lamu port infrastructure development in Northern Kenya was financed as a government initiative called the LAPSSET Corridor Programme. It is one of Eastern Africa's largest and most ambitious infrastructure projects aimed at integrating Kenya, Ethiopia and South Sudan.

Notwithstanding the wide variety in investment modes and investors' background and profiles, quite a few port developments in SSA are guided by (terminal) concessions. Under the concession system, the concessionaire obtains the right to use portland, infrastructure and facilities for a limited period of time, in exchange for the obligation to provide port (cargo handling) services (Farrell, 2012). The key features of a private concession are that the basic terminal infrastructure remains in public ownership, while terminal operations are controlled by a separate entity which is at least partly owned by private companies. The operator is given the right to use public assets for a specific period of time and operates with a large degree of commercial freedom (defined in the initial contract). In many but not all cases the operator also has the right (and often the obligation) to invest in the terminal. The adoption of concessions in SSA has necessitated various port institutional reform programmes which became a prerequisite for the inclusion of external investment partners interested in port or port terminal development concessions in the region. In practice, many SSA ports have adopted some sort of landlord port authority model. Under this model, the landlord port authority typically is a separate entity under public law established by specific legislation with the capacity to conclude contracts, enforce standards and to make rules and regulations applicable within the port area. Port operations (especially cargo-handling) are carried out by private companies (Verhoeven, 2010). Landlord port authorities are challenged to develop effective terminal awarding procedures in view of attracting private terminal operating companies. At the same time, a well-designed concession policy allows port authorities to retain some control on the organisation and structure of the supply side of the port market while optimizing the use of scarce resources (Notteboom, 2007). Theys et al. (2010) reviewed important questions related to the procedures in view of selecting the most appropriate operators for their scarce land and the conditions under which these companies can be given the right to operate the facilities. It is widely recognised that the awarding of port services to private operators has become one of the most important means for landlord port authorities to influence the prosperity of the port community (Pallis et al., 2008).

For example, the Port of Cotonou in Benin managed by the Port Autonome de Cotonou benefitted following the Millennium Challenge Corporation's (MCC) assistance in 2006. During this intervention, the United States was solicited as a donor for a USD 307m grant to develop port infrastructure on the South quay of the port of Cotonou. A condition of the funding was government commitment to introduce significant institutional reforms, which would enable the concession of container terminal facilities to a private operator through a 
competitive, fair and transparent process and modernised mechanisms associated with legal instruments such as terminal handling licences. This was a condition precedent to the disbursement of the MCC grant. Today, the port of Cotonou is occupied by three terminal operators, APM Terminals (private), SOBEMAP (public) and the Bolloré group (private). The dominant player is Bolloré on account of the group being awarded a concession for the newly built South Quay. The last major development of South Africa's portfolio of ports is the Port of Ngqura. Commissioned in 2009, Ngqura was developed with much political will in the Eastern Cape province, an economically underdeveloped region $17 \mathrm{~km}$ from an existing port, Port Elizabeth. Strategically intended to attract transshipment volume, the Ngqura port development has been severely criticised by various local and international port experts on the basis of the port's distance from international maritime routes and load centres (from the maritime dimension), as well as the port's distance from local and regional consumption and production markets. On the other hand, Ngqura has also been applauded as positive from a ship operating perspective. The single call option as a hub (if viable for carriers) is more advantageous than the multiple call options available to lines during the pre-Ngqura era (Notteboom, 2010). Unlike the Benin development, however, Ngqura remains held by a South African Government entity Transnet which is both the authority and operator of this port. The more recently commissioned New Container terminal in Walvis Bay (Namibia), similar to South African ports, institutionally remains an owned and operated government enterprise, i.e. Namport. The expansion of the new 750k TEU facility was funded by debt issued by the Southern African Development Bank and the project was completed in 2019.

The Beninese, Namibian and South African examples of port developments on the continent also reveal a level of institutional variation in the manner in which terminal concessions are being managed (publically or privately held). Indeed, a large variation exists in the way ports in SSA are organised and in terms of the nature of port authorities and terminal operators (Fraser and Notteboom, 2015b). Although there is a trend towards the privatisation of terminals, there are still some countries, which maintain the role of both the authority and terminal operator (South Africa, Kenya and Namibia to name a few). These governments remain institutionally locked into the notion that state-owned enterprises remain an appropriate vehicle for port terminal operations. The evolutionary economic concept of the path "lock-in" and "de-locking" to some extent has constrained institutional path evolution to exogenous influences (negative or positive) (Fraser and Notteboom 2015b). One of these constraints includes the introduction of new skills and capabilities to terminal operations, as well as alternative ownership models and funding mechanisms for capacitating terminal operations.

This "lock-in" comes at a great cost to government agencies/entities who typically borrow to invest. For example, in South Africa, Transnet National Port Authority (TNPA) and terminal operator Transnet Port Terminals (TPT), both part of Transnet, have in the past 15 years initiated significant capital investment programmes in the national ports. Transnet has also undertaken feasibility studies with a view to identifying viable long-term development options for additional terminal capacity in the South African port system (e.g. the Durban Dig Out Project (DDOP) on the current site of the old Durban airport located south of the city). To carry the heavy investment burden of such a major port infrastructure development, Transnet has already investigated the business rationale of funding arrangements, also including different options in terms of PPP. Although TNPA and TPT exist as ring-fenced divisions of Transnet providing each with a certain level of autonomy in decision-making with respect to business and operational decisions, the funding strategy (source and use of funds) ultimately resides in the hands of the holding corporate office, Transnet. This corporate parenting structure applied by Transnet to the entity's two-port businesses is in stark contrast with more recent port
Port funding strategies 
MABR

6,2

reform programmes like that of Benin, as well as other African port reform programmes such as in Mozambique and Madagascar. The current institutional position of Transnet, thus, implies a self-funding (off-balance sheet) strategy for the capital investment endeavours of both the TNPA and TPT portfolio of port businesses.

Against the above background, this study provides practical insight into the potential cost of a terminal concession for private or public sector participants and a view of the most advantageous funding strategy available for interested investors. This is undertaken with a particular focus on institutionally locked in state-owned port and port terminal enterprises within the regional context of sub-Saharan Africa.

\section{Terminal valuation approaches and funding strategies}

To fully appreciate a potential port investment opportunity, interested external investment partners/funders will need to have the assurance of the value of the business prior to determining the affordability of funding for the prospective investment. A robust business valuation is, therefore, necessary to inform the amount of funding required. PPP has been a popular instrument in SSA used by investors to unlock funding required for port infrastructure projects. This section provides an overview of the valuation methods and funding strategies available to concessionaires and outlines the theoretical framework on which this work's financial model is built.

\subsection{Business valuations methods}

Three main approaches to business valuations can be distinguished, namely:

(1) Asset-based;

(2) Income-based; and

(3) Cash flow-based.

In essence, asset-based valuations estimate a business as being worth the value of its total net assets. There are, however, three common methods of applying the asset-based approach, namely, the book value, net realisable values and replacement value methods (Garrett, 2012) as outlined in Table 1.

The second approach to entity valuation is income-based. Fundamentally, these methods consider the earning capability/potential of an entity during valuation. The method of priceearnings $(\mathrm{P} / \mathrm{E})$ ratios rely on finding listed companies in similar businesses to the company being valued (the target company) and then evaluates the relationship between the share price and earnings to determine the value of the company. The $\mathrm{P} / \mathrm{E}$ ratio is the price per share divided by the earnings per share and shows the number of years' worth of earnings paid for at the share price. The fundamental disadvantage with this approach is that it is based on speculative external historical market information of listed companies/industries which may not adequately represent the unlisted entity value being evaluated.

The cash flow-based valuation approach typically relies on the discounted cash flow method (DCF). The DCF method essentially applies prospective data using a relatively large number of assumptions related to (for example) future revenue, operational capital and funding costs, as well as general economic variables to determine the value of a business entity. The DCF analysis is a very powerful tool that is not only used to value companies but also to price IPOs and other financial assets. The method is widely used by professionals in investment banks, consultancies and managers around the world for a range of tasks and is even referred to as "the heart of most corporate capitalbudgeting systems" (Luehrman, 1998:, p. 51). The free cash flow is the amount of "cash 


\begin{tabular}{|c|c|c|c|c|}
\hline Approach & Key assumption & Advantages & Disadvantages & rt funding \\
\hline $\begin{array}{l}\text { The book value } \\
\text { approach }\end{array}$ & $\begin{array}{l}\text { The value of an asset or group } \\
\text { business assets is the historical } \\
\text { (sunk) acquisition costs less the } \\
\text { financial reporting determined } \\
\text { asset depreciation guided by the } \\
\text { asset's useful life }\end{array}$ & $\begin{array}{l}- \text { Relatively } \\
\text { simple to } \\
\text { calculate }\end{array}$ & $\begin{array}{l}\text { - Uses historic sunk costs } \\
\text { - Relies on arbitrary } \\
\text { depreciation } \\
\text { - Inventory and } \\
\text { receivables require } \\
\text { adjustments } \\
\text { - Does not consider the }\end{array}$ & 153 \\
\hline $\begin{array}{l}\text { Net realisable values } \\
\text { of the assets less } \\
\text { liabilities }\end{array}$ & $\begin{array}{l}\text { The value is the amount obtained } \\
\text { should the asset or group of } \\
\text { business assets be sold on the open } \\
\text { market subsequent to the liabilities } \\
\text { being settled }\end{array}$ & $\begin{array}{l}- \text { Relatively } \\
\text { simple to } \\
\text { calculate }\end{array}$ & $\begin{array}{l}\text { business's future cash- } \\
\text { generating potential } \\
\text { - Realisable value } \\
\text { becomes low due to port } \\
\text { assets being specialised } \\
\text { - Limited market } \\
\text { - Does not consider the } \\
\text { business's future cash- } \\
\text { generating potential }\end{array}$ & \\
\hline Replacement values & $\begin{array}{l}\text { The value is the cost to set up a } \\
\text { business if it were to be started as } \\
\text { a greenfield project }\end{array}$ & $\begin{array}{l}\bullet \text { Relatively } \\
\text { simple to } \\
\text { calculate }\end{array}$ & $\begin{array}{l}\text { - Does not consider the } \\
\text { business's future cash- } \\
\text { generating potential }\end{array}$ & $\begin{array}{r}\text { Table } 1 . \\
\text { Asset-based } \\
\text { approach }\end{array}$ \\
\hline
\end{tabular}

not required for operations or reinvestment" (Brealey et al., 2006:, p. 998). These free cash flows are then discounted using a discount rate that is matched to the flow's risk. The discount rate is referred to as a weighted average cost of capital (WACC) which will be discussed later in this paper.

There are two ways of using cash flows for the DCF valuation. You can either use the free cash flow to the firm (FCFF) which is the cash flow that is available to debt- and equity holders or you can use the free cash flow to equity (FCFE) which is the cash flow that is available to the company's equity holders only.

When using the FCFF, all input data has to be based on accounting figures that are calculated before any interest payments are paid out to the debt holders. The FCFE in contrast uses input data from which interest payments have already been deducted. Using the FCFF as a base for the analysis will result in the enterprise value of the company, using the FCFE will give the equity value. As an acquirer usually takes overall debt and equity, the $\mathrm{FCFF}$ is more relevant than the equity approach.

The FCFF is calculated by deducting taxes from the company's earnings before interest and taxes (EBIT), resulting in the net operating profit after tax (NOPAT), adding back noncashflow expenses and deducting capital expenditure (Capex) and the increase in net working capital (NWC).

The formula for calculating the FCFF is shown below (Damodaran, 1996, p. 237).

$$
F C F F=N O P A T+D \& A-\text { Capex }- \text { Increase in NWC }
$$

In consideration of the available valuation methods and given the requirements of this study, the authors will later recommend the development of a financial valuation model applying the commonly used cash flow discounting method, i.e. the Discounted Cash Flow Method (Section 4.2). The port concession will be regarded as a business, generally considered a cash-generating asset and will be evaluated as a financial asset. 
MABR

6,2

\subsection{Funding options}

Once the value of the organisation is determined using an appropriate valuation method, the next step is to determine the cost-effectiveness of the funding model to the Port Operator. In their study on port development and investment challenges in Southern Africa, Fraser and Notteboom (2015a) outlined generic sources of port funding (lending at no interest) and financing (lending regarded as an investment at a cost). Financing can be either through debt only, equity-only or a combination of debt and equity. Debt is generally considered a cheap source of finance. The cost of debt is lower than the cost of equity due to the assumed lower risk, lower expected returns and a tax shield/advantage. It is important to note that the cost of equity equals business risk plus financial risk. Business risk is dependent on the nature of the business. Financial risk is the risk that relates to the borrowing of long-term/shortterm loans. Financial gearing (taking on debt finance) improves the return to shareholders during good economic periods but may lower the return when the economy is struggling (Skae et al., 2012).

The traditional theory takes the view that debt finance is acceptable and will lower the overall company cost of finance as long as the company does not take on too much debt. The second theory, the Miller and Modigliani theory state that debt finance brings financial risk such that the cost of equity will increase (Skae et al., 2012, pp. 79-83). Investors, however, would expect a higher return on equity given high debt in the entity to offset the risk carrying liabilities. While debt funding retains ownership rights by the entity owners and may provide a tax benefit through the allowance of finance costs (as a business expense deduction), the borrowing comes with the financial burden to refund the loan capital within the agreed terms. Importantly also, finance costs/interest is also capitalised to the procured assets, which increases the asset base value. From a financial risk perspective, any breaches of loan covenants may have consequences such as an increase in finance costs, order payback or order liquidation. In addition, loans may require fixed monthly payments that may not match with the unpredictable business cash flows, thus placing the high financial risk on the company and its owners. Finally, loan repayments take funds out of the company, reducing the funds needed to finance growth.

As mentioned in the introduction, there are various funding sources for major developments such as ports. Some may be provided by the Development Finance Institutions (DFIs) in the region or other government organisations in the form of loans or grants.

More specifically, port operator concessionaires have the following main funding and finance options: development loan, equity and private or public grant funding.

Development loans are available from African DFIs. Borrowing in Africa and in other emerging markets is generally assessed as riskier than that of developed markets due to the greater perceived financial and business risks. Notwithstanding this fact, each potential investment is assessed and reviewed based on merit. The main advantage of a loan/debt is that the investor's ownership and/or dividends are not diluted. Conversely, the disadvantage is that repayments have strict contractual obligatory requirements/terms irrespective of how the business is performing financially.

In the case of equity, the investor responding to the port operator concession may from its reserves provide the capital to start up the operation. Equity is normally raised from the public issue of shares/securities. The listing of securities is regulated and at a minimum will require the sharing of voting rights effectively permanently selling ownership. With concessions, it is not usually the intention of the landlord to 
give ownership to the public. In addition, given this port terminal concession scenario, a given concession with a limited lifespan (years) may not attract the optimal number of investors to raise the funds required via a listed securities financing instrument.

Another available option consists of public or private grant funding. In a developing regional context, a grant can be a more attainable funding mechanism if the investment (or in this case) the concession agreement meets the generally strict qualification criteria stipulated by the grant. The main advantages of a grant are that no repayment is required and that there is no dilution of ownership for the potential investor. The availability of grants, however, is extremely constrained and the application process is both onerous and time-consuming. Grants often come with restrictions on the use of funds and in some cases require the investor to match the value of the grant with alternatively sourced financed funding (Grant, 2010).

There is an important link between port institutional arrangements and funding options available for port development. State-owned and operated ports with a $100 \%$ government ownership interest mandate are consequently constrained to debt funding options. Similar institutional arrangements, which, however, permit the introduction of private sector participation and dilute ownership provide broader funding options and introduce new risks and rewards for port development and future operations.
Port funding
strategies

155

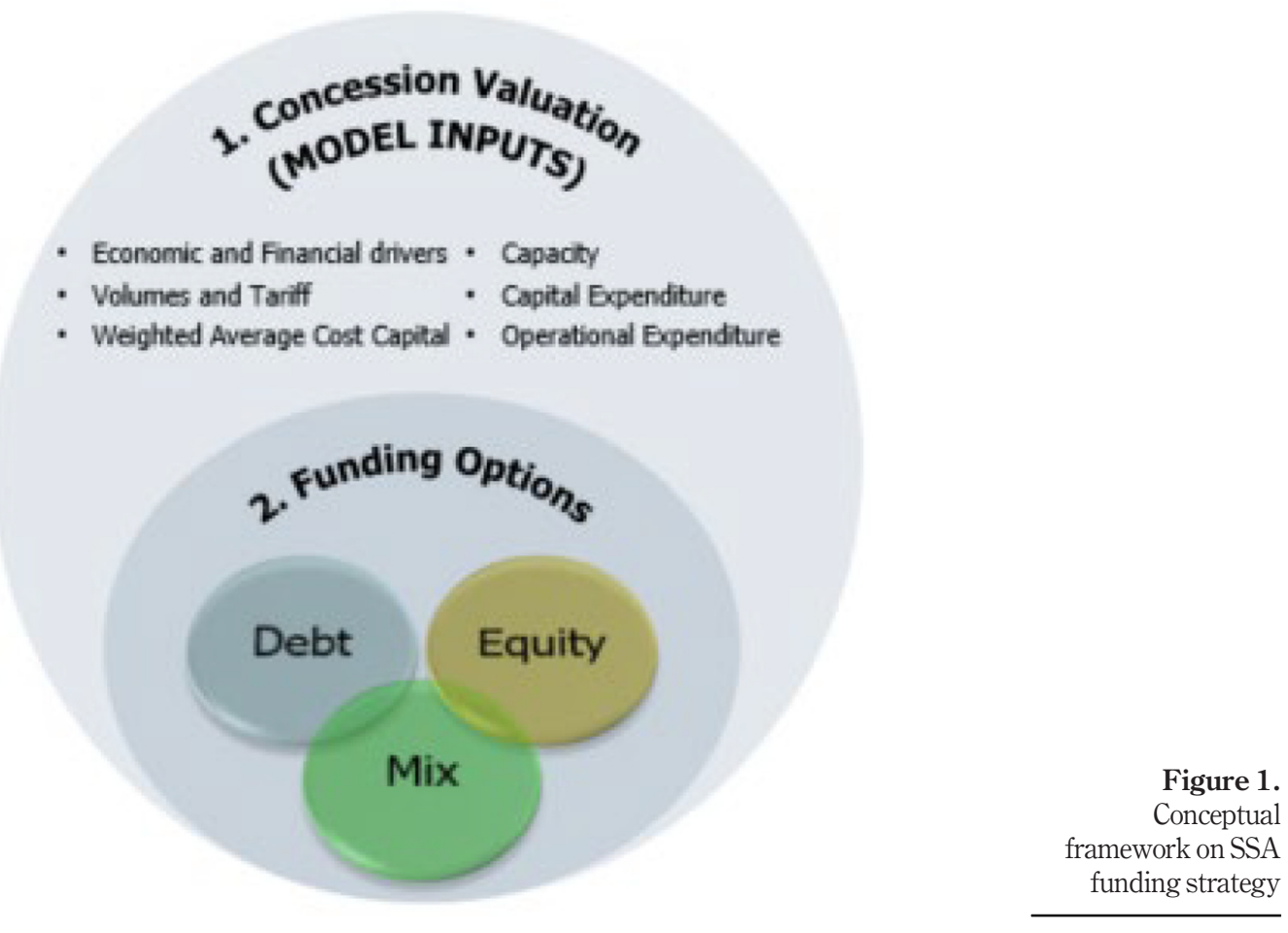


MABR

6,2

\section{Case study: the valuation and funding strategy of a two-berth container terminal}

The primary valuation and funding approach available to potential port concession investors were discussed in the previous sections. The application of the selected approach for the purpose of this study is provided in Figure 1 which outlines the conceptual framework valuation and funding options of this study. In this section, we apply this framework to a container terminal project.

\subsection{Unit of analysis, assumptions, research questions and methodology}

The objective of this study is to analyse and evaluate the implications of different funding strategies associated with the development of a two-berth port terminal in sub-Saharan Africa. For the purposes of this research, the authors consider/limit this study to the case of a two-berth container port concession agreement whereby an SSA port authority privatises a port terminal facility for a period of 25 years. Due to the often-extreme confidential manner with which terminal concession transactions are managed, sufficient data for a real case example was either not available or could not be used. Information with respect to equipment and funding costs, in conjunction with key transaction assumptions, however, provided sufficient detail for this hypothetical case.

The key assumptions of the case's concession agreement are as follows:

- The concession agreement is a port terminal concession comprising port superstructure; typical of a landlord port model where the port authority and port terminal are separate entities.

- The responsibility and costs associated with the port infrastructure build (quay walls, port perimeter, channel dredging, etc.) will remain the responsibility of the port authority.

- The terminal has an estimated annual container handling capacity of 400,000 TEU. The total quay wall length is assumed at 600 metres and the port's nautical accessibility constraints permit vessels with a maximum under keel clearance of $12.5 \mathrm{~m}$.

- The construction period is 4 years including infrastructure, superstructure and handling equipment.

- The concession period is 25 years and commences at the point in which construction of the port infrastructure is completed.

- Given the large geographical (southern, eastern or western) reach of SSA, as well as the different economic conditions and risk profiles within the region, for the purposes of this study, we confine our case to the Southern African Development Community (SADC) region. SADC is a regional economic community comprising 16 member states, i.e. 10 states with seaport(s) (i.e. Angola, Comoros, Democratic Republic of Congo, Madagascar, Mauritius, Mozambique, Namibia, Seychelles, South Africa and Tanzania) and six land-locked countries (i.e. Eswatini, Lesotho, Botswana, Malawi, Zambia and Zimbabwe). It is necessary to regionally confine the study as the economic, lending and risk profiles across the region are quite wide in range. Therefore, we focus this study on a specific region for the input values required during the financial modelling section of this paper to be reasonable for the given regional context. Thus, to ensure the selection of reasonable input assumptions (i.e. lending rates, inflation, etc.), the authors select the SADC region. 
The methodology applied to this study follows a quantitative approach using financial modelling techniques in which we will need to answer the following two research questions.

$R Q 1$. What is the financial value of the concession? The first step towards achieving the objective of this financially focussed quantitative approach is to generate the value for the said concession by using an appropriate financial valuation model.

$R Q 2$. What is the most cost advantageous funding strategy applicable to this concession? In step two, different funding strategies are applied to the model post valuation to determine the most cost advantageous funding instrument available to fund the concession given the local context and institutional constraints. This will be undertaken by applying different financial funding models.

In addition to determining results for questions 1 and 2 , the authors will also assess the extent to which the financial funding approach may influence the institutional arrangements of this hypothetical port concession. For the purpose of this research study, institutional arrangements are in reference to the extent of government ownership in the structure of the concession.

This study's primary focus is limited to the financial modelling methods associated with the valuation and funding of a two-berth container terminal in a sub-Saharan context. This implies the results are only valid for the chosen case study and can, thus, not be generalised to other port infrastructure projects. The case study is meant to demonstrate the application of an appropriate methodology and decision process when answering the two research questions. The authors have also used comparative world ports to derive high-level assumptions regarding the terminal capacity of the hypothetical terminal based on assumed port dimensions, types and quantities of handling equipment. In Sections 4.2 and 4.3, the assumptions, limitations and base variables of the valuation and funding models are described in some detail. Again, although case study research is useful for the purpose of testing theory (Yin, 1994), the results from case study research cannot be generalised.

\subsection{Valuation model selection}

Section 3 provided an overview of the available financial valuation techniques potentially applicable to this study's first research question. We now assess, using judgement based on the principles (provided in Section 3.1) each of the valuation techniques as it pertains to its applicability given our research objectives. The valuation technique selection applicability tests summarised in Tables 1 to 4 consider the key features of each valuation method in relation to pertinent practical considerations associated with port terminal concession characteristics. For example, within the asset-based approach, the net realisable value does not consider the cash-generating potential of the asset. Similarly, for the income-based approach, the $\mathrm{P} / \mathrm{E}$ ratio is benchmarked with similar listed entities which may not be fully comparable on account to differing port institutional arrangements. After the applicability test, a/the most suitable valuation technique(s) are then selected. An additional consideration with respect to the most suitable valuation technique selected is also the availability of data which is required as inputs in the valuation model. While the parameters of the case are predefined (as outlined in the key assumptions section of the concession case, see Section 4.1), the data used within these assumed parameters was based on the actual cost to revenue ratios, income values derived from actual terminal operating tariffs from an SSA terminal operator and actual financing variables (see Appendix).
Port funding strategies 
MABR

6,2

158

Having assessed the potential applicability of the asset-based valuation methods as they would be applied to an SSA valuation (Table 2), the authors determine these methods as not favourable and applicable to the valuation of a port terminal concession.

Having assessed the potential applicability of the income-based valuation of a Price Earnings valuation using Gordon's growth model as it would be applied to an SSA valuation (Table 3), the authors determine this method as not applicable to the valuation of a port terminal concession.

Based on Tables 2, 3 and 4, a cash flow based financial valuation model technique is most applicable to our case. As an acquirer usually takes over all liabilities, debt and equity, the FCFF is also more relevant than the equity approach. Effectively, for RQ1, the FCFF technique will be applied to this study to assess the value of the concession agreement in the case study, a two-berth container terminal with an annual handling capacity of 400,000 TEU.

Table 2.

Applicability test: asset-based valuation methods for port concessions

\begin{tabular}{|c|c|c|c|}
\hline $\begin{array}{l}\text { Applicability } \\
\text { test }\end{array}$ & Book value valuation & $\begin{array}{l}\text { sed approach valuation met } \\
\text { Net realisable valuation } \\
(\mathrm{NRV})\end{array}$ & $\begin{array}{l}\text { hods } \\
\text { Replacement value } \\
\text { valuation }\end{array}$ \\
\hline $\begin{array}{l}\text { Applicable to } \\
\text { concession } \\
\text { valuation? }\end{array}$ & Low & Moderate & Moderate \\
\hline Rationale & $\begin{array}{l}\text { - Book value is based on historic } \\
\text { sunk cost and does not take into } \\
\text { account market prices } \\
\text { - Values are adjusted with } \\
\text { accounting depreciation which } \\
\text { may not be aligned to market } \\
\text { values } \\
\text { - Book value does not consider } \\
\text { the cash-generating potential of } \\
\text { the asset } \\
\text { - The approach does not } \\
\text { consider the cost of goodwill }\end{array}$ & $\begin{array}{l}\text { - NRV of the assets may } \\
\text { be low due to port assets } \\
\text { being specialised in } \\
\text { nature } \\
\text { - NRV does not consider } \\
\text { the cash-generating } \\
\text { potential of the asset } \\
\text { - NRV does not consider } \\
\text { the cost of goodwill }\end{array}$ & $\begin{array}{l}\text { - Replacement value does } \\
\text { not consider the cost of } \\
\text { goodwill } \\
\text { - Replacement value does } \\
\text { not consider the cash } \\
\text { generating potential of the } \\
\text { asset }\end{array}$ \\
\hline
\end{tabular}

\section{Table 3.}

Applicability test, income-based valuation methods for port concessions
Income-based approach valuation

Applicability test

Price-earnings valuation with the application of Gordon's growth model
Applicable to concession Not applicable valuation?

Rationale
- $\mathrm{P} / \mathrm{E}$ ratio is benchmarked with a similar listed entity which may not be fully comparable on account to differing port institutional arrangements

- The value is based on historic market information

- Earnings can be subject to manipulation based on accounting treatment, certain financial non-disclosures, etc

- Assumes constant dividend which may not apply in a concession

- Assumes consistent dividend in perpetuity from year 1

- Concession has a limited lifespan and dividend is only payable once when there is cash available for dividends

- Assumes stable growth per annum 


\subsection{Application of the free cash flow from the firm method}

Based on the valuation model applicability test (Section 4.2), we select the free cash flow from the firm (FCFF) method as the technique most applicable to the valuation of the twoberth container concession in our case study. Table 5 provides an overview of the key assumptions in the FCFF model used as drivers for future years of cash generation and operation.

The volume demand (in 20-foot equivalent unit - TEU) serves as a key input for the revenue (cash generated) in the valuation model. Given that the focus of this study is primarily on the determination of an optimal funding strategy, the authors have not computed TEU volume forecast models but rather assumed a low probability step-up of volume traffic in line with a port in a developing SADC country accommodating container liner services generating a container throughput of 6,000 to 8,500 TEU per week capped to annual throughput of 400,000 TEU. A detailed schedule of the volume assumptions for the valuation model (in TEU) is provided in Appendix 4.

The base container handling tariffs applied in the model have been benchmarked with SADC tariffs and escalated to the year of inception with a mix for imports, exports and transhipment containers (TEU), weighted based on a TEU factor of 1.5. Note that transhipment refers to containers, which arrive and leave the terminal by ship, while import and export containers combine a sea leg with a land leg (by truck or rail). The base tariffs used are 3,078 ZAR for imports and exports and 1,845 ZAR for transhipments (one move over the quay).

The equipment required for the concession is informed by a container port operating philosophy to create a container handling capacity of 400,000 TEU. Given the fact that the focus of this paper is financial, a detailed operational model is not provided and the capacity of the terminal is assumed at 400,000 TEU. The authors have assumed a rubber-tired gantry (RTG) terminal with container handling equipment and prime moving assets with an initial capital investment cost of R1,471m ZAR (detailed in Table 6).

Sustaining capital expenditure costs would need to be provided for over the concession period escalated at cost, and in consideration of the useful life of each equipment component.

We generate the concession free cash flows through the application of the input variables discussed to:

$$
F C F F=N O P A T+D \& A-C a p e x-\text { Increase in NWC }
$$

The free cash flows are subsequently discounted to determine the concession valuation:

\begin{tabular}{|c|c|c|}
\hline Applicability test & $\begin{array}{l}\text { Cash-flow based }- \\
\text { Free cash flow from the firm } \\
\text { (FCFF) }\end{array}$ & $\begin{array}{l}\text { Dased approach valuation } \\
\text { Cash-flow based - } \\
\text { Free cash flow from the equity (FCFE) }\end{array}$ \\
\hline $\begin{array}{l}\text { Applicable to } \\
\text { concession } \\
\text { valuation? }\end{array}$ & High & High \\
\hline Rationale & $\begin{array}{l}\text { - Widely used to value companies } \\
\text { and to price IPOs and other } \\
\text { financial assets } \\
\text { - Considers cash flows available to } \\
\text { debt and equity holders }\end{array}$ & $\begin{array}{l}\text { - Widely used to value companies and to price IPOs } \\
\text { and other financial assets } \\
\text { - Only considers cash flows available to equity holders }\end{array}$ \\
\hline
\end{tabular}

Port funding strategies

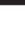


MABR

6,2

160
Financial model escalation assumptions/economic indicator

General cost escalation (CPI)

Capital cost escalation

Tariffs and escalation rate

Volume growth

Reporting currency

Labour costs

Hurdle rate

Operating expenses

Tax

Borrowings

WACC
Table 5.

Model inputs and key assumptions
Rate Rationale

$5.5 \%$

$6 \%$

$5.5 \%$

$3.5 \%$

ZAR

CPI +1

Verifying based on

WACC calculations

Appendix 3 EUR region
In line with the CPI in the Southern African Region

All operating equipment are purchased in USD and

Escalation is assumed to be CPI plus 0.5 basis points to cater for the impact of currency volatility

Tariffs are benchmarked with SADC port tariffs as a base and escalated in future years

Tariff escalation is in line with CPI

Traffic growth is in line with generalised SADC container growth. This value is capped at 400,000 TEU which is the assumed maximum capacity of the terminal facility. Refer to Appendix 4

South African Rand (ZAR)

The manning of the terminal is informed by the planned port handling equipment as provided in the capital investment schedule and the design capacity $\mathrm{CPI}+1$. This is in line with the labour trends in the

$\mathrm{WACC}+$ inflation $*=$ nominal WACC

nominal $\mathrm{WACC}^{* *}+$ project risk $^{* * *}$

* The real WACC plus inflation assumed in the SADC to average $5.5 \%$ effectively yields a nominal WACC

**Determined in Appendix 2 at gearing of $100 \%$, $50 \%, 45 \%$ and $0 \%$

**** Project risk $=$ we assume that the funder expects a premium of $4 \%$ to compensate for greenfield project risk associated with this concession Fixed operating costs comprise security costs, land rentals, municipal rates and taxes, materials, repairs and maintenance and other

Variable operating costs include labour overtime costs, casual labour, energy costs, water and contract payments

Total operating costs constitute between $34 \%$ and $42 \%$ of revenue

Company tax at $25 \%$ and VAT at $14 \%$

Benchmarked with the South African Rand (ZAR) prime rate of $10.5 \%$ plus a risk premium of $1.5 \%$. The assumed debt tenor of 15 years

Will differ based on the funding mix. Refer to Appendix 3 for WACC, Appendix 1 for the cost of equity and Appendix 2 for the cost of debt calculation

$\mathrm{V}=\frac{\mathrm{CF}_{1}}{(1+\mathrm{k})^{1}}+\frac{\mathrm{CF} 1_{2}}{(1+\mathrm{k})^{2}}+\ldots . \frac{\mathrm{CF}_{\mathrm{n}}}{(1+\mathrm{k})^{\mathrm{n}}}$ for the concession period

Where:

$\mathrm{CF} 1_{\mathrm{x}}=$ Free cash flow generated by the company in period; and

$\mathrm{k}=$ Weighted Average Cost of Capital. 
Project development costs (excluding VAT)

Total ZAR

Ship to shore cranes $\times 5$

Rubber tired gantry cane $\times 15$

Rail-mounted gantry crane $\times 2$

Haulers $\times 20$ (prime mover equipment)

Hauler trailers $\times 20$ (prime mover support)

Empty container handler $\times 4$

Reach stackers $\times 2$

Forklift $15 \mathrm{t} \times 1$

Forklift $7 \mathrm{t} \times 2$

Forklift 5 ton $\times 1$

Additional STS crane spreaders $\times 4$

Cherry picker $\times 1$

Headblock $\times 4$

Heavy lift hook (heavy lift) $\times 1$

Out of gauge spreader

IT network and systems

Buildings and other superstructure

Total development costs (ex VAT)
Port funding strategies

540.04

286.74

74.75

19.53

14.84

12.18

8.85

2.57

1.70

0.78

6.77

1.16

0.78

0.44

0.78

58.75

440.97

$1,471.64$
Table 6.

Initial investment superstructure costs

\subsection{The financial model and funding sources}

In line with the valuation applicability test and valuation technique selection assessment of 4.2, we review the range of selected funding sources associated with this concession and identify which is/are applicable to our case (Table 7). The key assumptions relating to the cost of debt, equity and the weighted average cost of capital which ultimately informed the funding model and the concession financial viability input variables for each of the debt and equity model scenarios are provided in Appendix 1 and 2 and $3 .$.

For determining the cost of equity the following formula was used: $C O E=r f+\beta(r m-r f)$, with $\mathrm{rf}=$ risk-free rate, $\mathrm{rm}=$ return from the market and $\beta=$ the beta value for a listed company in the same type of business (appropriately adjusted for gearing). An $11.22 \%$ COE (levered) is

\begin{tabular}{|c|c|c|c|}
\hline $\begin{array}{l}\text { Funding source } \\
\text { selection }\end{array}$ & Development loan & $\begin{array}{l}\text { Sources of funding } \\
\text { Equity }\end{array}$ & Public grants \\
\hline $\begin{array}{l}\text { Applicability of the } \\
\text { funding source to the } \\
\text { concession funding } \\
\text { strategy }\end{array}$ & High & High & Low \\
\hline Rationale & $\begin{array}{l}\text { - Debt funding is available } \\
\text { on application } \\
\text { - The investor's ownership } \\
\text { and/or dividends are not } \\
\text { diluted } \\
\text { - Loans have strict } \\
\text { contractual obligatory } \\
\text { requirements/terms } \\
\text { irrespective of how the } \\
\text { business is performing } \\
\text { financially }\end{array}$ & $\begin{array}{l}\text { - Availability of equity } \\
\text { funding may be limited } \\
\text { - Listed securities } \\
\text { instruments are not } \\
\text { available for concessions } \\
\text { with a limited lifespan }\end{array}$ & $\begin{array}{l}\text { Criteria for grants are } \\
\text { generally stringent } \\
\text { - Grants are rare. } \\
\text { - Limited funding } \\
\text { availability } \\
\text { - No dilution of } \\
\text { ownership }\end{array}$ \\
\hline
\end{tabular}

Table 7.

Funding source selection 
MABR

6,2

\section{2}

applied in the case study based on $\mathrm{rf}=8.825 \%, \mathrm{rm}=11 \%$ and $\beta=1.1$ (see Appendix 1 ). The case study's financial data for the cost of debt amounts to $9 \%$ based on a pre-tax interest rate of $12 \%$ and a tax rate of $25 \%$ (Appendix 2). For $100 \%$ equity funding, an unlevered COE of $10.61 \%$ is applied (Appendix 3).

\subsection{Overall results on terminal valuation and optimal funding strategies}

Applying the valuation and funding assumptions, as well as the model inputs, the salient model result values are provided (i-viii) in Table 8 . This is based on four financing scenarios, namely; $100 \%$ debt, $50 \%$ debt, $45 \%$ debt and $100 \%$ equity. The selected scenarios firstly apply the two funding extremes for both debt and equity at $100 \%$, secondly a balanced view for each at $50 \%$ for both debt and equity and a minority debt funding approach at $45 \%$. An extract of the DCF evaluation associated with each of the four scenarios is disclosed in Appendix 5. The concession valuation results consider a range of funding approaches, effectively the mix of debt and equity. These options are in effect the funding strategies we have selected- the results of which are disclosed in Table 8 (ii-viii) which will drive the discussion to answer $R Q 2$. The fundamental assumption made is that the cost of equity, project risk premiums and the investors' expectation on returns will not change with the changes in gearing. This funding range selection demonstrates the impact of the mix of debt and equity on the concession's salient financial outputs.

It is demonstrated that the WACC changes depending on the extent of the gearing - level of debt. The most highly geared option (100\% debt) results in the lowest WACC in our case. Conversely, $100 \%$ equity results in the highest WACC.

The capital requirement value provides the total cost associated with the CAPEX provision given the funding mix. Our results demonstrate a $100 \%$ debt to be the most expensive - on account of borrowing costs capitalised.

The Net present value (NPV) is one of the outputs from the concession valuation model; a positive result demonstrating the financial viability of the concession based on the model assumptions. Reviewing the NPV results we observe that $100 \%$ debt yields the highest NPVs while $100 \%$ equity yields the lowest. This difference is a result of the higher WACC associated with $100 \%$ equity funding.

The total equity value result effectively answers $R Q 1$ by providing a range of financial values associated with a range of funding strategies. If the objective is to achieve the highest value of the concession, a 100\% debt funding strategy would be favoured. The lowest value on the other hand is $100 \%$ equity. Interestingly, the difference in value between $100 \%$ debt vs $50 \%$ debt (272) is greater than $100 \%$ equity

Table 8.

Results of the valuation and funding models (iii)

\begin{tabular}{|c|c|c|c|c|c|c|}
\hline $\begin{array}{l}\text { (i) } \\
\text { Concession } \\
\text { valuation }\end{array}$ & $\begin{array}{l}\text { (ii) } \\
\text { Hurdle } \\
\text { rate } \\
(\%)\end{array}$ & $\begin{array}{l}\text { (iii) } \\
\text { Capital requirement } \\
\text { including } \\
\text { construction interest } \\
\text { (million ZAR) }\end{array}$ & $\begin{array}{c}\text { (iv) } \\
\text { Net present } \\
\text { value (million } \\
\text { ZAR) }\end{array}$ & $\begin{array}{c}(\mathrm{v}) \\
\text { Total entity } \\
\text { value (million } \\
\text { ZAR) }\end{array}$ & $\begin{array}{l}\text { (vi) } \\
\text { Discounted } \\
\text { payback } \\
\text { period } \\
\text { (years) }\end{array}$ & $\begin{array}{c}\text { (vii) } \\
\text { IRR (\%) }\end{array}$ \\
\hline $100 \%$ debt & 18.50 & $1,506.01$ & 1.170 .01 & $2,676.02$ & 9.83 & 31 \\
\hline $50 \%$ debt & 19.60 & $1,492.16$ & 911.95 & $2,404.11$ & 10.75 & 30 \\
\hline $45 \%$ debt & 19.70 & $1,492.16$ & 895.15 & $2,387.31$ & 10.83 & 30 \\
\hline $100 \%$ equity & 20.10 & $1,476.61$ & 732.72 & $2,209.33$ & 11.83 & 28 \\
\hline
\end{tabular}


vs $50 \%$ equity (-195). This also illustrates how the introduction of greater debt funding increases the value of the concession.

The discounted payback period provides the period (in years) required to repay the initial investment. In total, $100 \%$ debt once again appears to be the most favourable having the shortest payback period.

The internal rate of return (IRR) is the discount rate which makes the net present value of the concession equal to zero. Generally speaking, the higher the NPV, the more desirable it is to undertake the concession. Based on our case results, $100 \%$ debt provides (generally speaking) the most favourable IRR, although the observed differences in IRR are small.

Overall, the optimal funding strategy given our case of a 25 year two-berth container terminal concession in the SADC region of SSA depends on the financial goals of the organisation's management or shareholders. For example, based on our results, if the firm is seeking the highest business valuation for the concession with the shortest payback period, then a $100 \%$ debt funding strategy should be selected. These positive goals will, however, be traded off for higher overall (more expensive) capital requirements. From an institutional ownership perspective, this funding strategy can be applied to both a publicly or privately owned concession with a 100\% debt funding strategy. In this instance, there appears to be no disparity in the financial evaluation results irrespective of whether the concession is either public or privately owned, the use of only debt to fund the concession would yield the same results.

As the ratio of debt reduces, however, the financial results similarly deteriorate. In all instances of debt structuring less than $100 \%$, the investment valuation, total equity value and IRR are reduced. In addition, the discounted payback period is also extended. On the other hand, as the equity ratio increases, the capital requirements value then reduces, in essence, capital expenditure becomes cheaper.

Table 9 discloses the total debt (capital and interest) associated with the concession investment requirements given $100 \%, 50 \%$ and $45 \%$ debt funding. Notwithstanding the fact that interest is a tax-deductible variable in the DCF model providing a more favourable NPV result, interest from debt does, however, introduce other risks and considerations to the financial position for the concessionaire. During the construction phase, all interest from the debt is capitalised to the assets. This results in a higher cost base for assets financed by high-interest debt (which is typical within SSA) compared to assets funded by financing options with limited finance costs. A higher asset base, as a result of excessive capitalised interest, places a burden with respect to the Return On Asset (ROA) requirements for the terminal equipment. Effectively, assets with an overstated base value will require higher yielding returns in the production process to realise the organisation's ROA targets. In addition, overstated assets when evaluated in terms of International Accounting Standard IAS 36 could become impaired if the asset's carrying amount exceeds the assets recoverable

\begin{tabular}{|c|c|c|c|c|}
\hline Funding options (R'm) & $100 \%$ debt & $50 \%$ debt & $45 \%$ debt & \\
\hline Drawdowns (initial investment) & $-1,480.83$ & -666.37 & -664.89 & \\
\hline Capitalised interest & -25.18 & -11.33 & -11.31 & Table 9. \\
\hline Total capital debt & $-1,506.01$ & -677.70 & -676.20 & Debt funding \\
\hline Interest & & & & options: the interest \\
\hline Total interest and fees paid & 888.19 & 395.81 & 394.93 & burden \\
\hline
\end{tabular}

Port funding strategies

163

$-$


MABR

6,2 amount. The recoverable amount represents the returns from the asset and could be constrained by uncontrollable external factors. While debt is the institutionally locked in the mechanism of funding for (in particular) state-owned terminal operators in SSA (see the paper's introduction), the implications of debt on the operator's asset cost base and the ability to realise reasonable ROA returns could be compromised. As such the risk of impairment, therefore, will require careful consideration during the determination of the extent of debt selected.

From an institutional perspective, this funding strategy can be applied to an instance where publicly or privately owned concessionaires invite potential investors to participate in the concession investment. This mixed funding approach dilutes ownership for both the publicly/privately owned concessionaires. In addition, the value of the investment (concession valuation) is eroded, the payback period increased and the IRR reduced. For a publicly owned concessionaire such as SOBEMAP (Benin), Transnet (South Africa), NAMPORT (Namibia) or Kenya Ports Authority (Kenya) pursuing a private equity partner for a prospective terminal operation based on these financial results would not be favoured. If, however, these publicly held terminal concessionaires had severe balance sheet borrowing constraints (unable to secure debt), then the inclusion of an equity partner could be a viable consideration with an ownership/control trade-off. Overall, from a purely financial valuation and investment appraisal perspective, $100 \%$ debt funding in our SADC case is the optimal financial instrument for the funding of this hypothetical concession. There does, however, need to be careful consideration of the potential gearing risks such as loan covenant breaches, as well as the impact interest capitalised has on the funded assets ROA and exposure to potential asset impairment.

\section{Conclusion}

This study analysed and evaluated the implications of different funding strategies associated with the case of a hypothetical two-berth port container terminal development in sub-Saharan Africa (SSA). The results of the study illustrated a range of financial investment appraisal results from the case study concession in consideration of four specific funding strategies. For each strategy, the research objectives; i.e. determining a valuation of the concession and identifying the most advantageous funding strategy applicable to the said concession, were achieved. In addition, other financial investment appraisal indicators such as the Internal Rate of Return and the discounted payback periods were provided to gauge the attractiveness of the concession to potential investors interested in an SSA port terminal concession.

The results revealed that the highest concession valuation could be attributed to a higher debt ratio as a principle funding strategy(in this case and context). In addition, this funding approach $(100 \%$ debt) realised the shortest payback period and highest IRR values. The authors, however, maintain that the optimal funding strategy for a concession depends ultimately on the financial goals of the investor. From a financial valuation/investment appraisal perspective there appears to be no incentive for publicly held terminal operators capable of independently raising debt to invite equity partners to share the risks and rewards associated with the potential concession. Based on these results, the public entity would only do so if it had severe balance sheet borrowing constraints. Notably, this work confirms the traditional theory that debt finance is acceptable and will lower the overall company cost of finance as long as the company does not take on too much debt (Skae et al., 2012, pp. 79-83). Due consideration for potential covenant default risks associated with a 
highly geared balance sheet must also be carefully assessed. A concessionaire's ability to generate revenue may be impacted by a number of exogenous factors, which could negatively influence container throughput (for example) and consequently cash flows. This would then put severe pressure on the concessionaire's ability to completely meet loan obligations. A more complicated consideration associated with high-interest debt funding is the capitalisation of high finance/borrowing costs to port terminal assets. This may compromise the ROA targets of the concessionaire and also may induce asset impairments due to the pressure a high asset base value could place on a concessionaire's ability to generate reasonable returns.

There is scope to advance this work by exploiting some of the limitations of this study. This can be done by undertaking an operations simulation model based on the size of the concessioned terminal, vessel and quayside operational norms, truck/vessel arrivals and terminal gate activity (to name a few). The output of such an operation simulation model would provide a more in-depth approach to the determination of the capital expenditure, refining the model results.

\section{References}

Brealey, R.A., Myers, S.C. and Allen, F. (2006), Principles of Corporate Finance, 8th ed., McGraw-Hill, New York, NY, p. 998.

Cheon, S., Dowall, D. and Song, D. (2010), "Evaluating impacts of institutional reforms on port efficiency changes: ownership, corporate structure, and total factor productivity changes of world container ports", Transportation Research Part E: Logistics and Transportation Review, Vol. 46 No. 4, pp. 546-561.

Cook, C.T. (2010), "Funding Port-Related infrastructure and development: the current debate and proposed reform", Fordham Urb. LJ, Vol. 38, p. 1523.

Damodaran, A. (1996), Investment Valuation, John Wiley and Sons, New York, NY.

Farrell, S. (2012), "The ownership and management structure of container terminal concessions", Maritime Policy and Management, Vol. 39 No. 1, pp. 7-26.

Farrell, S. (2014), "Attracting private finance into African ports", in Meersman, H., Van de Voorde, E., Vanelslander, T. (Eds), Port Infrastructure Finance, Informa Law from Routledge, 181-209.

Fraser, D.R. and Notteboom, T. (2015a), "Port development in Sub Saharan Africa: competitive forces, port reform and investment challenges in: dynamic shipping and port development in the globalised economy", in Lee, P.T. and Cullinane, K. (Eds), Emerging Trends in Ports, Vol. 2, Palgrave Macmillan, Basingstoke, pp. 53-78.

Fraser, D. and Notteboom, T. (2015b), "Institutional development paths in seaports: the Southern African case", European Journal of Transport and Infrastructure Research (EJTIR), Vol. 15 No. 4, pp. 506-535.

Garrett, K. (2012), "Business valuations”, SA TECHNICAL - Business Valuations, Vol. 2, pp. 1-8.

Grant, L. (2010), "Nasdaq”, available at: www.nasdaq.com/article/four-traditional-funding-methods-forsmall-businesses-cm40099\#/ixzz4VqKwN9ki (accessed 4 February 2019).

Haralambides, H. (2002), "Competition, excess capacity and the pricing of port infrastructure", International Journal of Maritime Economics, Vol. 4 No. 4, pp. 323-347.

Lee, P.T.W., Hu, Z.H., Lee, S.J., Choi, K.S. and Shin, S.H. (2018), "Research trends and agenda on the belt and road (B\&R) initiative with a focus on Maritime transport", Maritime Policy and Management, Vol. 45 No. 3, pp. 282-300.

Luehrman, T.A. (1998), "Investment opportunities as real options”, Harvard Business Review, Vol. 51.
Port funding
strategies

165 
MABR

6,2
Musso, E., Ferrari, C. and Benacchio, M. (2006), "Port investment: profitability, economic impact and financing”, Research in Transportation Economics, Vol. 16, pp. 171-218.

Notteboom, T. (2007), "Concession agreements as port governance tools", Research in Transportation Economics, Vol. 17, pp. 449-467.

Notteboom, T. (2010), "From multi-porting to a hub port configuration: the South African container port system in transition", International Journal of Shipping and Transport Logistics, Vol. 2 No. 2, pp. 224-245.

Pallis, A.A., Notteboom, T. and De Langen, P.W. (2008), "Concession agreements and market entry in the container terminal industry", Maritime Economics and Logistics, Vol. 10 No. 3, pp. 209-228.

Satta, G., Notteboom, T., Parola, F. and Persico, L. (2017), "Determinants of the long-term performance of initial public offerings (IPOs) in the port industry", Transportation Research Part A: Policy and Practice, Vol. 103, pp. 35-153.

Skae, F.O., Vigario, F.A.A., Benade, F.J.C., Graaf, A., De Esterhuse, L., Jonke, W.D., Ndlovu, S., Nobyati, A.E., Pienaar, A.J., Plant, G.J., Steyn, B.L. and Steyn, N. (2012), Managerial Finance, 6th ed., Interpak Books Pietermaritzburg.

Theys, C., Notteboom, T.E., Pallis, A.A. and De Langen, P.W. (2010), "The economics behind the awarding of terminals in seaports: towards a research agenda", Research in Transportation Economics, Vol. 27 No. 1, pp. 37-50.

Trujillo, L., González, M. and Jiménez, J. (2013), “An overview on the reform process of African ports”, Utilities Policy, Vol. 25, pp. 12-22.

Verhoeven, P. (2010), “A review of port authority functions: towards a renaissance?”, Maritime Policy and Management, Vol. 37 No. 3, pp. 247-270.

World Bank (2020), "The World Bank in Africa: overview", 20 April 2020, available at: www. worldbank.org/en/region/afr/overview

Xiao, Y., Ng, A., Yang, H. and Fu, X. (2012), “An analysis of the dynamics of ownership, capacity investments and pricing structure of ports", Transport Reviews, Vol. 32 No. 5, pp. 629-662.

Yin, V. (1994), Case Study Research: Design and Methods, Sage, London.

\section{Further reading}

Brigham, E.F. and Ehrhardt, M.C. (2005), Financial Management: Theory and Practice, 11th ed., United States of America: Thomson South Western, pp. 9-6.

Investing.com (2017), www.investing.com, available at: www.investing.com/rates-bonds/south-africagovernment-bonds (accessed 5 May 2019).

Ross, S.A., Westerfield, R.W. and Jordan, B.D. (2008), Fundamentals of Corporate, 6th ed.. McGraw-Hill Irwin, New York, NY, p. 426.

Simkins, Z.S. and Stewart, R.D. (2015), "Factoring a real value of cargo in port investment and funding decisions", Maritime Policy and Management, Vol. 42 No. 7, pp. 712-728.

\section{Corresponding author}

Theo Notteboom can be contacted at: theo.notteboom@gmail.com 
$\mathrm{rf}=$ risk-free rate:

$\mathrm{rm}=$ return from the market; and

$\beta=$ the beta value for a listed company in the same type of business, appropriately adjusted for gearing.

The case study financial data shows the following for leveraged equity:

$$
\begin{aligned}
& \mathrm{rf}=8.825 \%(\mathrm{a}) \\
& \mathrm{rm}=11 \%(\mathrm{~b}) \\
& \beta=1.1(\mathrm{c}) \\
& \text { COE }(\text { levered })=8.825 \%+1.1(11 \%-8.825) \\
& \text { COE }(\text { levered })=11.22 \%
\end{aligned}
$$

Notes

a) $\mathrm{rf}$ - It is considered that yields from government bonds are risk-free. Risk-free rate is based on 10 years bond rate. Botswana 4.9, Kenya 14.01, RSA 8.825. The median being RSA was chosen: Sourced from www.investing.com/rates-bonds/south-africa-government-bonds

b) $\mathrm{rm}$ is the historical return of the stock market for a similar stock market industry. A return of $11 \%$ is assumed for this exercise.

c) $\beta$ - measures the sensitivity of the share price to changes in the market. Beta is highly influenced by financial and operating leverage. The Beta applied to the case was benchmarked with similar port business with similar gearing of $45 \%$ using an average over a 5 year period.

The case study financial data shows the following for unlevered equity beta:

Unlevered beta $=$ levered beta/[1 $+(1-$ Tax rate $) *($ debt/equity $)]$

Levered beta $=1.1$

Tax rate $=25 \%$

Debt/equity $=45 \%$

$0.82=1.1 /[(1+(1-0.28) * 0.45)]$

COE (unlevered $)=8.825 \%+0.82(11 \%-8.825)$

$\mathrm{COE}($ unlevered $)=10.61 \%$

\section{Appendix 2. Cost of debt}

$$
C O D=i *(1-t)
$$

where:

$\mathrm{i}=$ pre-tax interest rate $-12 \%$; and

$t=$ tax rate $-25 \%$.

The case study financial data shows the following:

$$
C O D=12 \% x(1-0.25)=9 \%
$$


MABR

6,2
Appendix 3. Weighted average cost of capital and hurdle rate calculation

$$
W A C C=((E / V) * R e)+[((D / V) * R d) *(1-T)]
$$

where:

$\operatorname{Re}=$ cost of equity:

$\mathrm{Rd}=$ cost of debt:

$\mathrm{E}=$ market value of the firm's equity:

$\mathrm{D}=$ market value of the firm's debt:

$V=E+D$

$\mathrm{E} / \mathrm{V}=$ percentage of financing that is equity:

$\mathrm{D} / \mathrm{V}=$ percentage of financing that is debt; and

$\mathrm{Tc}=$ corporate tax rate .

The case study financial data shows the following:

- $\quad$ Equity = R820,630,758.

- Debt = R671,425,169.

- $\operatorname{Re}=11.22 \%$.

- $\mathrm{Rd}=9 \%$.

- Tax rate $=25 \%$.

To find WACC at $45 \%$ gearing:

$\mathrm{WACC}=\left[\left(\frac{820630758}{820630758+671425169}(* 0.1122)\right]+\left[\left(\frac{671425169}{820630758+671425169} * 0.12 *(1-0.25)\right]\right.\right.$

$\mathrm{WACC}=6.17 \%+4.05 \%=10.22 \%$

Hurdle rate at $45 \%$ gearing $=10.22 \%+5.5 \%+4 \%=19.7 \%$

To find WACC at $50 \%$ debt:

- $\quad$ Equity = R738,325,812.

- $\quad$ Debt $=$ R738,325,912.

- $\operatorname{Re}=11.22 \%$.

- $\operatorname{Rd}=9 \%$.

- $\quad$ Tax rate $=25 \%$.

$\mathrm{WACC}=\left[\left(\frac{738325912}{738325912+738325912}(* 0.1122)\right]+\left[\left(\frac{738325912}{738325912+738325912} * 0.12 *(1-0.25)\right]\right.\right.$

$\mathrm{WACC}=5.61 \%+4.50 \%=10.11 \%$

Hurdle rate at $50 \%$ gearing $=10.11 \%+5.5 \%+4 \%=19.6 \%$

To find WACC at $100 \%$ debt:

- $\quad$ Equity = R0.

- Debt = R1,506,010,910.

- $\operatorname{Re}=11.22 \%$.

- $\operatorname{Rd}=9 \%$.

- Tax rate $=25 \%$.

$\mathrm{WACC}=\left[\left(\frac{0}{0+1506010910}(* 0.1122)\right]+\left[\left(\frac{1506010910}{0+1506010910} * 0.12 *(1-0.25)\right]\right.\right.$

$\mathrm{WACC}=0 \%+9 \%=9 \%$

Hurdle rate at $100 \%$ gearing $=9 \%+5.5 \%+4 \%=18.5 \%$

To find WACC at $100 \%$ equity (unlevered): 


$$
\begin{aligned}
& \text { WACC }=\left[\left(\frac{1476651824}{1476651824+0}(* 0.1061)\right]+\left[\left(\frac{0}{1476651824+0} * 0.12 *(1-0.25)\right]\right.\right. \\
& \text { WACC }=0 \%+10.61 \%=10.61 \% \\
& \text { Hurdle rate at } 100 \% \text { equity }=10.61 \%+5.5 \%+4 \%=20.1 \%
\end{aligned}
$$

Note: the WACC is normally used to discount a project's future cash flows, however, this rate may be increased for project-specific risks associated with the project. In this case study, due to the project being a greenfield (new) project, we assumed an additional risk rate of $4 \%$ to effectively give a project target rate. The target rate is also referred to as the project hurdle rate. 
MABR

6,2

170

Table A1.

Detailed schedule of the volume assumptions for the valuation model (in TEU)

\section{Appendix 4}

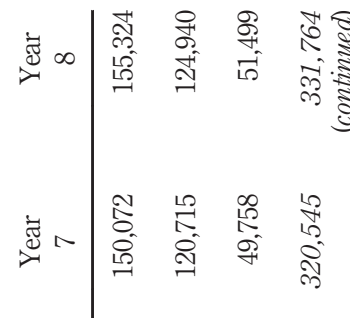

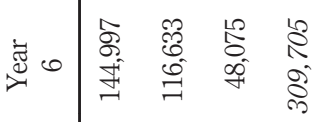

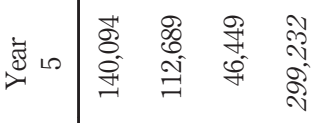

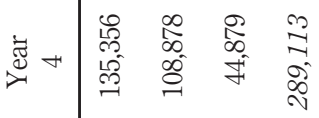

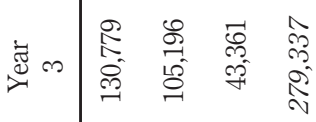

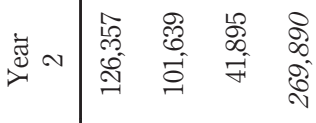

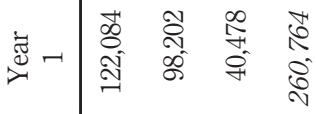

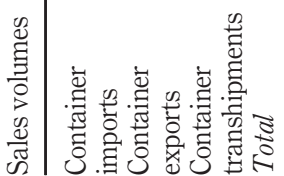




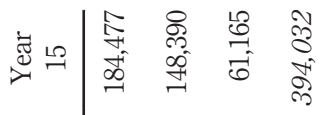

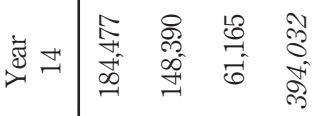

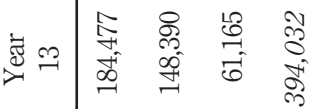

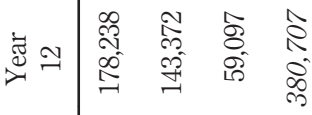

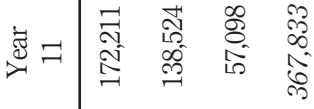

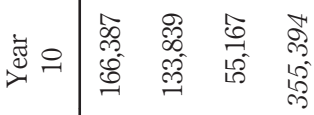

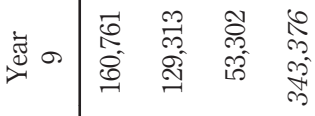

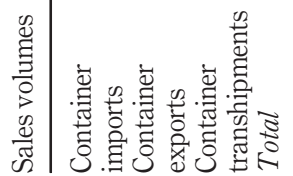


MABR

6,2

\section{2}

\section{Appendix 5. DCF evaluation associated with each of the four scenarios}

\section{$100 \%$ equity}

\begin{tabular}{|c|c|c|c|c|c|c|c|c|c|c|c|}
\hline \multirow[b]{2}{*}{$R^{\prime} m$} & \multirow[b]{2}{*}{ Total } & \multirow{2}{*}{\begin{tabular}{|l}
$\begin{array}{l}\text { Construction } \\
\text { start to end }\end{array}$ \\
$2017-2021$ \\
\end{tabular}} & \multicolumn{9}{|c|}{ Operation start to end } \\
\hline & & & 2022 & 2023 & 2024 & 2025 & 2026 & 2027 & 2028 & 2029 & $2030-2046$ \\
\hline Earinings Before Interest \& Tax (EBIT) & 44492 & - & 517 & 580 & 646 & 724 & 808 & 909 & 987 & 1097 & 38224 \\
\hline Less tax & -11123 & - & -129 & -145 & -162 & -181 & -202 & -227 & -247 & -274 & -9556 \\
\hline Net Operating Profit After Tax (NOPAT) & 33369 & - & 388 & 435 & 485 & 543 & 606 & 682 & 740 & 823 & 28668 \\
\hline Depreciation \& Amortisation & 3389 & - & 84 & 84 & 84 & 84 & 84 & 74 & 93 & 97 & 2704 \\
\hline Gross cash flows & 36758 & - & 472 & 519 & 569 & 628 & 690 & 756 & 833 & 920 & 31372 \\
\hline Capital expenditure & -4198 & -1472 & - & - & -6 & -41 & -54 & -65 & -34 & -30 & -2496 \\
\hline Increase in working capital & .726 & - & -6 & -7 & -9 & -11 & -13 & -15 & -17 & -19 & -629 \\
\hline Free cashflows & 31834 & -1472 & 466 & 512 & 553 & 576 & 623 & 676 & $\overline{782}$ & 870 & 28248 \\
\hline Hurdle rate & $20,1 \%$ & & & & & & & & & & \\
\hline Sum of discounted free cash flows & 733 & -1012 & 187 & 171 & 154 & 133 & 120 & 108 & 104 & 97 & 672 \\
\hline
\end{tabular}

\section{$45 \%$ debt}

\begin{tabular}{|c|c|c|c|c|c|c|c|c|c|c|c|}
\hline \multirow[b]{2}{*}{$\mathrm{R}^{\prime} \mathrm{m}$} & \multirow[b]{2}{*}{ Total } & \multirow{2}{*}{\begin{tabular}{|l}
$\begin{array}{l}\text { Construction } \\
\text { start to end }\end{array}$ \\
$2017-2021$ \\
\end{tabular}} & \multicolumn{9}{|c|}{ Operation start to end } \\
\hline & & & 2022 & 2023 & 2024 & 2025 & 2026 & 2027 & 2028 & 2029 & $2030-2046$ \\
\hline Earinings Before Interest \& Tax (EBIT) & 45920 & - & 523 & 587 & 656 & 737 & 822 & 927 & 1008 & 1121 & 39539 \\
\hline Less tax & -11480 & - & -131 & -147 & -164 & -184 & -206 & -232 & -252 & -280 & -9885 \\
\hline Net Operating Profit After Tax (NOPAT) & 34440 & - & 392 & 441 & 492 & 552 & 617 & 695 & 756 & 841 & 29654 \\
\hline Depreciation \& Amortisation & 3551 & - & 100 & 100 & 100 & 100 & 100 & 90 & 109 & 113 & 2737 \\
\hline Gross cash flows & 37990 & - & 492 & 541 & 592 & 653 & 717 & 785 & 865 & 954 & 32391 \\
\hline & 4198 & 1472 & 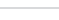 & 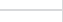 & 6 & -41 & -54 & 65 & 3 & 30 & -2496 \\
\hline Increase in working capital & -726 & - & -6 & -7 & -9 & -11 & -13 & -15 & -17 & -19 & -629 \\
\hline Free cashflows & 33067 & -1472 & 486 & 534 & 577 & 601 & 650 & 705 & 814 & 905 & 29266 \\
\hline & & & & & & & & & & & \\
\hline WACC & $19,7 \%$ & & & & & & & & & & \\
\hline Sum of discounted free cash flows & 895 & -995 & 198 & 182 & 164 & 143 & 129 & 117 & 113 & 105 & 741 \\
\hline
\end{tabular}

\section{$50 \%$ debt}

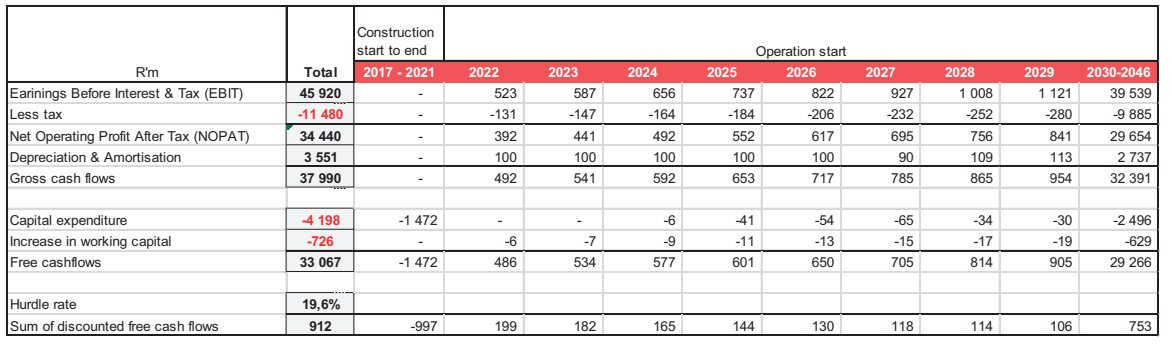

\section{$100 \%$ debt}

\begin{tabular}{|c|c|c|c|c|c|c|c|c|c|c|c|}
\hline \multirow[b]{2}{*}{$\mathrm{R}^{\prime} \mathrm{m}$} & \multirow[b]{2}{*}{ Total } & \multirow{2}{*}{\begin{tabular}{|l|}
$\begin{array}{l}\text { Construction } \\
\text { start to end }\end{array}$ \\
$2017-2021$ \\
\end{tabular}} & \multicolumn{9}{|c|}{ Operation start } \\
\hline & & & 2022 & 2023 & 2024 & 2025 & 2026 & 2027 & 2028 & 2029 & 2030-2046 \\
\hline Earinings Before Interest \& Tax (EBIT) & 45722 & - & 503 & 568 & 636 & 717 & 803 & 907 & 988 & 1102 & 39499 \\
\hline Less tax & -11430 & - & -126 & -142 & -159 & -179 & -201 & -227 & -247 & -275 & -9875 \\
\hline NOPAT & 34291 & - & 377 & 426 & 477 & 538 & 602 & 680 & 741 & 826 & 29624 \\
\hline Depreciation \& Amortisation & 3748 & - & 120 & 120 & 120 & 120 & 120 & 110 & 129 & 133 & 2776 \\
\hline Gross cash flows & 38040 & - & 497 & 546 & 597 & 658 & 722 & 790 & 870 & 959 & 32400 \\
\hline Capital expenditure & -4198 & -1472 & - & - & -6 & -41 & -54 & -65 & -34 & -30 & -2496 \\
\hline Increase in working capital & -726 & - & -6 & -7 & -9 & -11 & -13 & -15 & -17 & -19 & -629 \\
\hline Free cashflows & 33116 & -1472 & 491 & 539 & 582 & 606 & 655 & 710 & 819 & 910 & 29276 \\
\hline Hurdle rate & $18,5 \%$ & & & & & & & & & & \\
\hline Sum of discounted free cash flows & 1170 & -979 & 210 & 195 & 177 & 156 & 142 & 130 & 127 & 119 & 894 \\
\hline
\end{tabular}

